\title{
変形性膝関節症に対する高位怪骨々切り術の経験
}

\author{
広島大学整形外科
}

長谷川修・永山五。哉

小山鉱三

\section{Experience of High Tibial Osteotomy for Osteo-arthritis of The Knee}

By

\section{O. Hasegawa, Y. Nagayama \& K. Oyama}

The Department of Orthopedic Surgery, Hiroshima University, School of Medicine

我々は過去 3 年間に変形性膝関節症に対し 10 例 の 高位脛骨々切り術を施行した.

症例はいずれも臨床症状およびレ線写真にて変形性 膝関節と診断され, かつ内反変形を伴い, 立位レ線写 真にて内側関節裂隙の狭少化および同部の骨硬化像が 著明なむので, 臨床的には, 膝の疼痛により長距離の 歩行が不能な 10 例である.

性別は男性 5 人, 女性 5 人で, 年令は 49 才より 72 才まで, 平均 62 才である.

発症より手術 までの 期間は 1 年より 10 年で平均 5.5 年であった.

術後の経過観察期間は 6 力月より 2 年 9 力月で平均 1 年 7 力月である.

骨切り術前にうけた治療は, 対症療法として, ステ ロイド関節注入や理学療法を受けたもの 8 例, 滑液膜 切除術を施行しているもの 2 例であるが, 今回の手術 症例はいづれもそれらの治療の効果が見られなかった あのである.

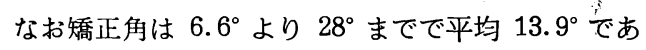
った.

\section{〈術前, 術後の症状およびレ線像の比較〉}

1. 疼痛

術後, 疼痛の改善の著明な症例 5 例, 改善のみられ たもの 3 例, 不変のあの 2 例であった.

本法の最あ大きな目的の一つが疼痛の改善であるの で, これは, そのまま術後成績, ひいては患者の満足 度につながった。

\section{2. 関節貯溜液}

6 例は術前より関節眝溜液が認められ，そのうち 3 例が改善し， 3 例は不変であった.

3. 運動制限

術後 3 例に改善がみられ，6例が術後に復し，1例 が悪化している.

元来, 本法は関節外の手術であり, 後療法む早期に 行えるので手術により関節拘縮を来すととは少なく， むしろ疼痛改善により関節可動域は良くなる.

4. 表 1 のでとく, 術前より, 多少関節可動域の制 限はあるが, 術後 $1 \sim 2$ 力月で $90^{\circ}$ ぐらい可能とな り, 術後 6 力月あすると, ほとんど術前と同じになる (表 1).

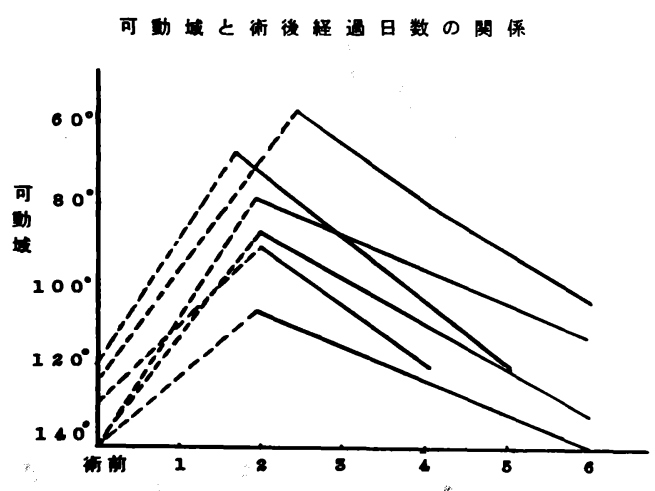

表 1 術後経過日数 (月)

5. 歩行能力

術後 1 例をのぞき改善されている. 歩行能力は疼痛 
と密接な関係があり, 疼痛が改善されれば歩行状態も 良くなる。

6. レ線像の変化

主に骨棘形成, 骨硬化像, 骨摩滅についてその変化 は術前, 術後比較したが，原疾患が変形性膝関節症で あるから，術前よりいくらか，骨の変化は認められ， すべての症例で術後, 程度の 差はあるが進行してい る. 特に経過観察の長いものほど, その傾向は強く, これは経年的な退行性変化であると思われる. しかし レ線的所見が強いものが，必らずしも症状が悪いとい うことはなかった。

以上総合的に術後成績を判定すると, 優 5 例, 良 3 例, 可 2 例であった.

\section{〈術後成䋶と年令, 矯正角, 関節貯溜液との比較〉}

1. 年令之術後成績

年令別に術後成績を分けると次のようになった，60 才以下では優が 1 例，良が 3 例，可が 1 例で， 70 才 以下では優が 2 例，良扔よび可がなく，70才以上で は優が 2 例，良がなし，可が 1 例であった，以上のご とく我々の症例では, 特に高令だから術後成績が悪い ということはなかった。

\section{2. 矯正角之術後成績}

表 2 のごとく，我々の症例では $5^{\circ}$ ぐらい過矯正に した方が術後成績は良いが, 症例 3 のごとく, 術後の FTA が $185^{\circ}$ と矯正角がたらなくても優の症例ああ る(表 2 ).
表 2 矯正角上術後成績

\begin{tabular}{|c|c|c|c|}
\hline 症 例 & 矯 正 角 & 術後 FTA & 術後成績 \\
\hline 1 & 7 & 180 & 良 \\
2 & 6.5 & 180 & 可 \\
3 & 16 & 183 & 優 \\
4 & 7 & 180 & 良 \\
5 & 8 & 180 & 可 \\
6 & 8 & 180 & 良 \\
7 & 20 & 177 & 優 \\
8 & 20 & 175 & 優 \\
9 & 20 & 175 & 優 \\
10 & 28 & 177 & 優 \\
\hline
\end{tabular}

3. 関節貯溜液と術後成績

術前に関節貯溜液のない症例は 4 例であり, すべて 術後成績は優である. 関節眝溜液のみられる場合は滑 液膜切除術を行なうべきであろう.

次に症例を 2 例供覧する.

症例 3,67 才の男子で 5 年来, 両滕関節に疼痛, 腫 脹を来し, 来院した. ステロイド関節注入, 滑液膜切 除術を施行し, 腫脹は軽快するも疼痛は増強し, 歩行 も困難となる。

術前 FTA $199^{\circ}$ の右膝に対し $16^{\circ}$ 外反骨切り術を 施行, 術後 FTA $185^{\circ}$ にした. 乙の症例は矯正角が 不十分で心配したが, レ線写真でも, 骨欠損部は形成 され，術前の骨と同じような形態となった。そして臨 床的に屯疼痛はほとんど消失し, 長時間の歩行も可能 となり現在では野良仕事も行なえるようになっている (図1).

症例 7,72 才の男性で 6 年来右膝に疼痛を訴え受診 した．初診時，かろうじて歩行可能の状態であった.

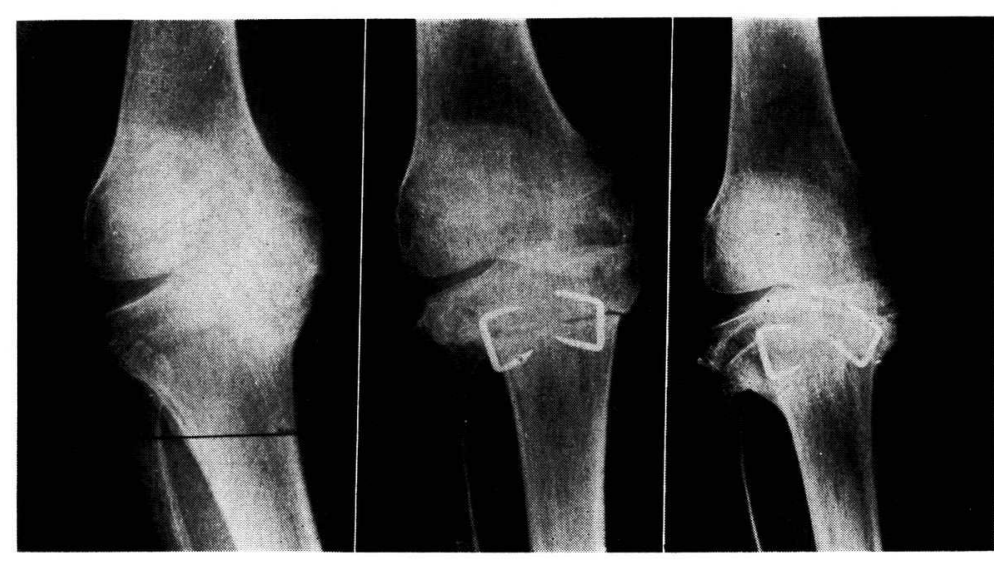

Pre. Op.

Post Op. 2 Yrs 8 Mos.

図 1 


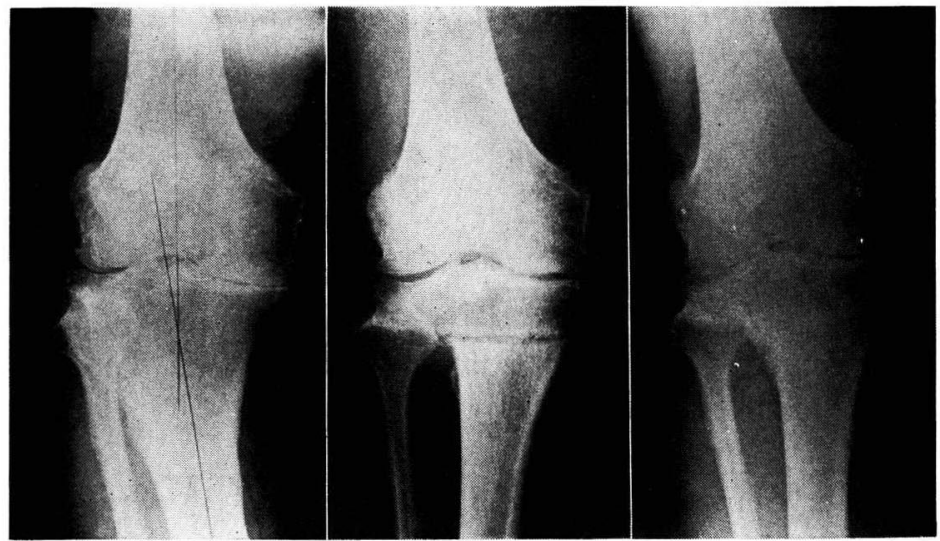

Pre. Op.

Pos Op. 2 Mos.

Post Op. 1 Yr.

四 2

術前 FTA $195^{\circ}$ で $20^{\circ}$ 外反骨切り術を施行し, 術後 FTA $175^{\circ}$ とする.レ線的には術後, 脛骨外側に大き な骨欠損を来し，術後早期の体重负荷時に問題がある と思われた. しかし術後 1 年で骨欠損部は形成されて いる. 現在, 術後 1 年であるが, 疼痛も軽快し一本杖 で長距離の歩行も可能である(図 2 ).

\section{考察〉}

我々の症例を検討し次の結果を得た.

1. 術後成績はあまり年令に左右されない.

2.レ線的変化は必らずしも症状と一致しない.

3. 術後に関節可動域が悪くなることはない.

4. 関節貯溜液の多いものは術後成績も良くなく, 関節貯溜液の軽快も多くは期待できない. 滑液膜切除 術あ行なうべきであろう。

5. 矯正角は約 $5^{\circ}$ 過矯正の方が術後成績は良い. しかし矯正角が不十分であ術後成績が良い症例むあ 万。

6. 矯正角が強い場合，楔状骨切りは骨欠損が大き くなるのでドーム骨切りが良いであろう.
以上我々の症例は検討したが，少数例で十分な検討 ができなかったが報告した。

本法は適応さえ良ければ有効な手術法と考える.

質問, 追加

久留米大学整形外科 横 田 清 司

追 加

59 才の男性で膝の spontaneous osteonecrosis に 対して high tibial osteotomy を行い良好な結果を 得たので追加した.

手術方法は脛骨結節の直上を線状に内側より骨切り を行い, 内側を開き同部を plate で固定し，内側の間 隙には骨切りの直下より採取した移植骨片を充填する 方法をとった.

質 問

術後，足関節痛を訴えたものはなかったか。

解 答広島大整形外科 長谷川修 術後, 足関節に疼痛を訴えるものはないかに対し, 我々の症例ではありませんでした. 